\title{
Induction of in vitro roots cultures of Thypha latifolia and Scirpus americanus and study of their capacity to remove heavy metals
}

\author{
María del Socorro Santos-Díaz* \\ Centro de Investigación y Estudios de Posgrado \\ Facultad de Ciencias Químicas \\ Universidad Autónoma de San Luis Potosí \\ Manuel Nava 6, San Luis Potosí \\ CP 78210, México \\ Tel: 4448262440 \\ Fax: 4448262372 \\ E-mail: ssantos@uaslp.mx \\ María del Carmen Barrón-Cruz \\ Centro de Investigación y Estudios de Posgrado \\ Facultad de Ciencias Químicas \\ Universidad Autónoma de San Luis Potosí \\ Manuel Nava 6, San Luis Potosí \\ CP 78210, México \\ Tel: 4448262440 \\ Fax: 4448262372

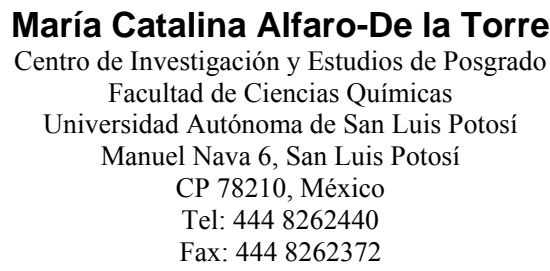

Financial support: We are grateful to SHIGO-CONACYT (2002-060-205) for financial support and for the scholarship to MCBC (2002-020605).

Keywords: heavy metals, in vitro root cultures, phytoremediation, Scirpus americanus, Thypha latifolia.

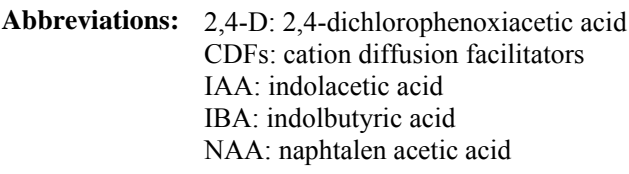

We have established the conditions to obtain in vitro root cultures of Thypha latifolia and Scirpus americanus and have investigated their capacity to remove $\mathrm{Pb}(\mathrm{II})$, $\mathrm{Mn}$ (II) and $\mathrm{Cr}$ (III) from the culture medium. The best conditions for the in vitro culture growth were: an inoculum of $0.2 \mathrm{~g}$ of $\mathrm{T}$. latifolia roots and $0.05 \mathrm{~g}$ of $S$. americanus roots (fresh weight), Murashige-Skoog medium and $2 \mathrm{mg} \mathrm{L-1of}$ indolacetic acid. The T. latifolia and $S$. americanus root cultures were cultivated onto media containing $\mathrm{Cr}\left(15 \mu \mathrm{L} \mathrm{L}^{-1}\right), \mathrm{Pb}\left(60 \mu \mathrm{L} \mathrm{L}^{-1}\right)$ or $\mathrm{Mn}$ (1.8 $\mathrm{m} \mathrm{L} \mathrm{L}^{-1}$ ). Both species were able to remove $\mathrm{Pb}$ and Cr near to $100 \%$ and $71-100 \%$ of $\mathrm{Mn}$ from the medium solution during the 6-8 days of experimentation. According to metal concentrations removed from the medium containing the growing root mass, the in vitro root culture of $S$. americanus can be considered as an accumulator for $\mathrm{Pb}\left(157.73 \mu \mathrm{g} \mathrm{g}^{-1}\right), \mathrm{Cr}\left(55.6 \mu \mathrm{g} \mathrm{g}^{-1}\right)$ and Mn (5000 ug g $\left.^{-1}\right)$.
Heavy metals are toxic pollutants that have serious adverse effects on human health. They are toxic because can replace other essential metals in pigments or enzymes, disrupting the function of these molecules (Manios et al. 2003). Also because they may cause oxidative stress, especially transition metals as $\mathrm{Fe}^{2+/ 3+}$ and $\mathrm{Cu}^{+/ 2+}$ (Rivetta et al. 1997).

The removal of metals from solution using plants offers an attractive alternative, because it is solar driven and can be carried out in situ, minimizing cost and human exposure (McCutcheon and Schnoor, 2003). Plants have developed different mechanisms of tolerance to the metals and to the metal accumulation. Some plants excrete organic acids, as malate and citrate, that act as metal chelators and decrease the rhizospheric $\mathrm{pH}$ increasing the bioavailability of metals for phytoextraction (Pivetz, 2001). Organic acids can also inhibit metal uptake because they complex the metal

${ }^{*}$ Corresponding author 
Table 1. Uptake of $\mathrm{Pb}, \mathrm{Cr}$ and $\mathrm{Mn}$ by in vitro root cultures of Thypha latifolia and Scirpus americanus.

\begin{tabular}{|c|c|c|c|c|c|}
\hline \multirow{2}{*}{ Metal } & \multirow{2}{*}{$\begin{array}{c}\text { Time } \\
\text { (days) }\end{array}$} & \multicolumn{2}{|c|}{ T. Iatifolia } & \multicolumn{2}{|c|}{ S. americanus } \\
\hline & & Dry weight (mg) ${ }^{1}$ & Uptake (\%) & Dry weight $(\mathrm{mg})^{1}$ & Uptake (\%) \\
\hline \multirow{5}{*}{$\mathrm{Pb}(\mathrm{II})$} & 0 & $6.51 \pm 1.4 \mathrm{a}$ & 50.62 & 3.11 & 55.75 \\
\hline & 2 & $8.23 \pm 1.4 a$ & 89.66 & 48.35 & 96.72 \\
\hline & 4 & $7.92 \pm 0.9 a$ & 96.76 & 57.86 & 100.00 \\
\hline & 6 & $6.50 \pm 1.1 \mathrm{a}$ & 97.53 & 58.24 & 100.00 \\
\hline & 8 & $7.14 \pm 0.7 a$ & 95.37 & 57.26 & 100.00 \\
\hline \multirow{5}{*}{$\mathrm{Cr}(\mathrm{III})$} & 0 & $5.78 \pm 1.3 \mathrm{a}$ & 33.97 & 39.33 & 47.25 \\
\hline & 2 & $6.71 \pm 1.3 a$ & 87.45 & 40.33 & 86.59 \\
\hline & 4 & $6.30 \pm 1.3 \mathrm{a}$ & 90.64 & 44.8 & 88.48 \\
\hline & 6 & $6.61 \pm 1.7 \mathrm{a}$ & 90.89 & 46.15 & 92.95 \\
\hline & 8 & $6.86 \pm 1.9 a$ & 92.89 & 52.78 & 90.04 \\
\hline \multirow{5}{*}{$\mathrm{Mn}(\mathrm{II})$} & 0 & $6.05 \pm 1.1 \mathrm{a}$ & 9.17 & 171.2 & 4.56 \\
\hline & 2 & $7.36 \pm 2.0 \mathrm{a}$ & 16.00 & 188.38 & 39.00 \\
\hline & 4 & $7.46 \pm 2.5 a$ & 64.67 & 191.66 & 76.89 \\
\hline & 6 & $6.93 \pm 2.2 \mathrm{a}$ & 70.89 & 204.91 & 89.00 \\
\hline & 8 & $6.84 \pm 2.3 a$ & 71.00 & 202.82 & 100.00 \\
\hline
\end{tabular}

${ }^{1}$ Means with different letter on the same column differed significantly $(P \leq 0.05)$.

outside the root (phytostabilization). For example, citrate inhibits $\mathrm{Al}$ and $\mathrm{Cu}$ uptake in some plant species (De la Fuente et al. 1997; Murphy et al. 1999). The high metal tolerance may be in part due to the highly efficient intracellular compartmentalization. The uptake of metals requires their transport across the root cell membrane to the

a
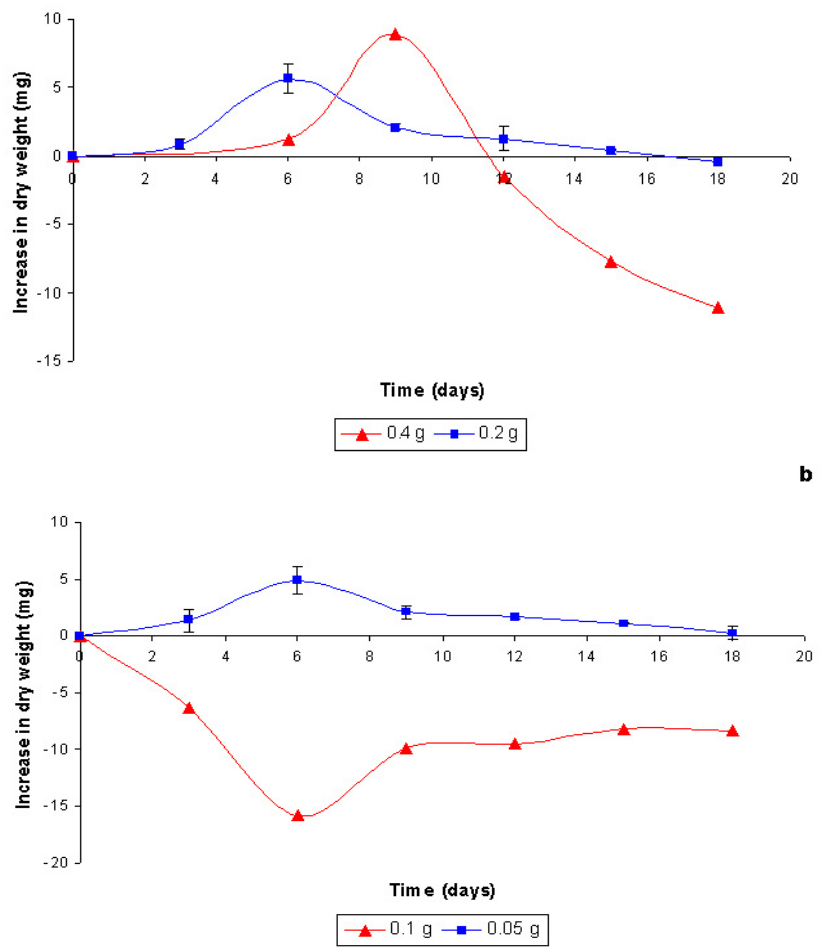

Figure 1. Time course of growth of:

(a) Thypha latifolia.

(b) Scirpus americanus roots cultured on hormone-free medium. symplast. This process involves specific membrane transporter proteins as heavy metal ATPases (HMAs), the natural resistance-associated macrophage proteins (Nramps), and cation diffusion facilitators (CDFs) (Hall and Williams, 2003). Once inside the cell, the metals could be translocated to their final destination by membrane metal transporters, and metal-binding proteins as metallothioneins (Goldsbrough, 2000). Metal chaperones are a different class of proteins that bring metals to specific targets in the cell (Himelblau et al. 1998). For the storage in the vacuole (sequestration), certain metals may be complexed by phytochelatins. These compounds are synthesized enzymatically from glutathione. Complex of metals bound by glutahione or phytochelatins are shuttled to the vacuole by an ATP-binding cassette $(\mathrm{ABC})$ type transporter protein in the tonoplast. Other metal-binding molecules that are involved in the metal complexation in the vacuole are organic acids (Kramer et al. 2000) and sulphides, in the particular case of cadmium (Cobbett, 2000). Additional mechanisms of tolerance are the assimilation of metals into organic molecules by metal-modifying enzymes (e.g. selenate is metabolized to dimethylselenide) or the changes in the oxidation state of metals that reduce their toxicity (e.g. toxic Cr VI is reduced to the non toxic Cr III; Lytle et al. 1998; De Souza et al. 2000).

The plants are efficient in the removal metals from their solid or liquid environment as also the plant cell cultures do. In vitro culture of plant organs (roots and shoots) allow indefinite propagation and experimentation using tissues derived from the same plant, thus avoiding the effects of variability between individual specimens. Axenic conditions in culture prevent microbial symbiosis disguising the metal uptake characteristics of plants grown in soil. Experiments using separately cultured organs also 
Table 2. Maximum removal of $\mathrm{Pb}, \mathrm{Cr}$ and $\mathrm{Mn}$ by Thypha latifolia and Scirpus americanus root cultures.

\begin{tabular}{|c|c|c|}
\hline Metal & T. latifolia $\left(\boldsymbol{\mu g} \mathbf{~ g}^{-\mathbf{1}}\right)^{\mathbf{a}}$ & S. americanus $\left(\boldsymbol{\mu g} \mathbf{~ g}^{-\mathbf{1}}\right)^{\mathbf{a}}$ \\
\hline $\mathrm{Cr}$ & $90.0(6)$ & $158.7(4)$ \\
\hline $\mathrm{Mn}$ & $20.4(8)$ & $55.6(6)$ \\
\hline $\mathrm{Pb}$ & $1867(8)$ & $5000(8)$ \\
\hline
\end{tabular}

${ }^{\mathrm{a}}$ The number in parenthesis represents the day in which maximum metal uptake was observed.

allow the metal accumulation properties of each organ to be identified. Some examples include the removal of $\mathrm{Sr}^{2+}$ by shoots of Solanum laciniatum (Kartosentono et al. 2001), and hyper-accumulation of $\mathrm{Cd}$ by hairy roots of Thlaspi caerulescens (Nedelkoska and Doran, 2000). Another advantages of in vitro cultures is the facility to obtain variants with different tolerance to several biotic stresses (Ben-Hayyim, 1987; Santos-Díaz and Ochoa-Alejo, 1994).

Some plants that have potential on phytoremediation are Thypha latifolia (reed mace) and Scirpus americanus (american tule). These species are able to grow on water bodies contaminated with heavy metals formed as result of industrial and domestic effluents (Montante-Montelongo et al. 1995) or in sludge compost watered with metaliferus water (Manios et al. 2003).

This work is focused on T. latifolia and S. americanus plants growing on an artificial lake contaminated with $\mathrm{Pb}$, $\mathrm{Cr}, \mathrm{Fe}, \mathrm{Ni}, \mathrm{Cu}$ and $\mathrm{Mn}$, known as Tenorio Tank. This tank has an extension of 209 ha and represent a serious problem of pollution beside to be the habitat of several species of water birds (Montante-Montelongo et al. 1995). It has been observed that the lake areas colonized by the T. latifolia and $S$. americanus plants shows better quality of water than those areas absent of vegetation. Therefore, it is plausible that the aquatic plants are participating on phytoremediation process. As the roots are in direct contact with water they should be the main responsible for the pollutants removal.

On the basis of this observations, the aim of this research was to develop a protocol to establish the in vitro roots cultures of T. latifolia and S. americanus and later on to investigate if they have the capacity to remove $\mathrm{Pb}(\mathrm{II})$, $\mathrm{Mn}$ (II) and $\mathrm{Cr}(\mathrm{III})$. Their concentrations are the most important in the water column of Tenorio Tank. Because phytoremediation and phytomining requires growth of the plants, the experiments were carried out in nutrient media under conditions supporting the root growth.

\section{MATERIALS AND METHODS}

The T. latifolia and S. americanus roots were collected from plants growing on the Tenorio Tank. Segments of roots $(5$ to $10 \mathrm{~cm}$ ) were washed for 3 days on a soap solution and then were rinsed with tap water. They were treated with $5 \%$ sodium hypochloride- $0.2 \%$ Tween-20, during $15 \mathrm{~min}$ and transferred to a quarter strength concentration of Murashige-Skoog medium, 1/4 MS (Murashige and Skoog, 1962) containing $10 \mathrm{ml} \mathrm{L}^{-1}$ Plant Preservative Mixture (PPM) for $24 \mathrm{hrs}$. The roots were transferred to liquid MS medium supplemented with 116 $\mu \mathrm{M}$ myo-inositol, $1.2 \mu \mathrm{M}$ thiamine- $\mathrm{HCl}$ and $3 \%$ sucrose. The $\mathrm{pH}$ of the media was adjusted to 5.7 after addition of the auxins indolacetic acid (IAA), indolbutyric acid (IBA), naphtalen acetic acid (NAA) or 2,4-dichlorophenoxiacetic acid (2,4-D). The media were sterilized at $120^{\circ} \mathrm{C}$ for 20 $\min$.

The roots were cultured in $250 \mathrm{ml}$ flasks on a orbital shaker operated at $130 \mathrm{rpm}$ and maintained at $25^{\circ} \mathrm{C}$ and photoperiod of $16 \mathrm{hrs} \mathrm{light}\left(45 \mu \mathrm{mol} \mathrm{m} \mathrm{m}^{-2} \mathrm{~s}^{-1}\right)$ and $8 \mathrm{hrs}$ dark. Previous to the experiments of metal removal the roots were subcultured every 15 days during 2 months to have active growing cultures. The growth of the roots was measured as increased on dry weight. The roots of $T$. latifolia and S. americanus were placed on $50 \mathrm{ml}$ flasks with $10 \mathrm{ml}$ medium MS containing $\mathrm{Cr}\left(15 \mu \mathrm{g} \mathrm{L}^{-1}\right), \mathrm{Pb}(60$ $\left.\mu \mathrm{g} \mathrm{L}^{-1}\right)$ or $\mathrm{Mn}\left(1.8 \mathrm{mg} \mathrm{L}^{-1}\right)$. The media of three flasks of each treatment, were collected by filtration and the removal of metals from solutions was quantified every 2 days, during 8 days. The samples were acidified with $3 \mu 1 \mathrm{~mL}^{-1}$ $\mathrm{HNO}_{3} 0.02 \mathrm{~N}$, filtrated through membranes $(0.22 \mu \mathrm{M}$ pore size) and place on HDPE flasks. The metals concentration was analyzed using an Atomic Absorption Spectrophotometer (3110 Perkin Elmer with graphite furnace). The quality control of the metal analysis was performed using a reference water (Riverine SLRS-3 water; NRC-CNRC, Canada) added to the culture media to simulate the sample matrix composition. The metal recovery during the analysis varied between $85-110 \%$ of the certified concentration of the reference material.

Three replications per treatment and two independent experiments were included per analysis. In order to evaluate statistically and significant differences among mean values, an ANOVA and Tukey test were used at the significance level of $95 \%$.

\section{RESULTS}

To establish the in vitro root cultures $0.4 \mathrm{~g}$ or $0.2 \mathrm{~g}$ of fresh roots of $T$. latifolia, and 0.1 and $0.05 \mathrm{~g}$ of roots of $S$. 

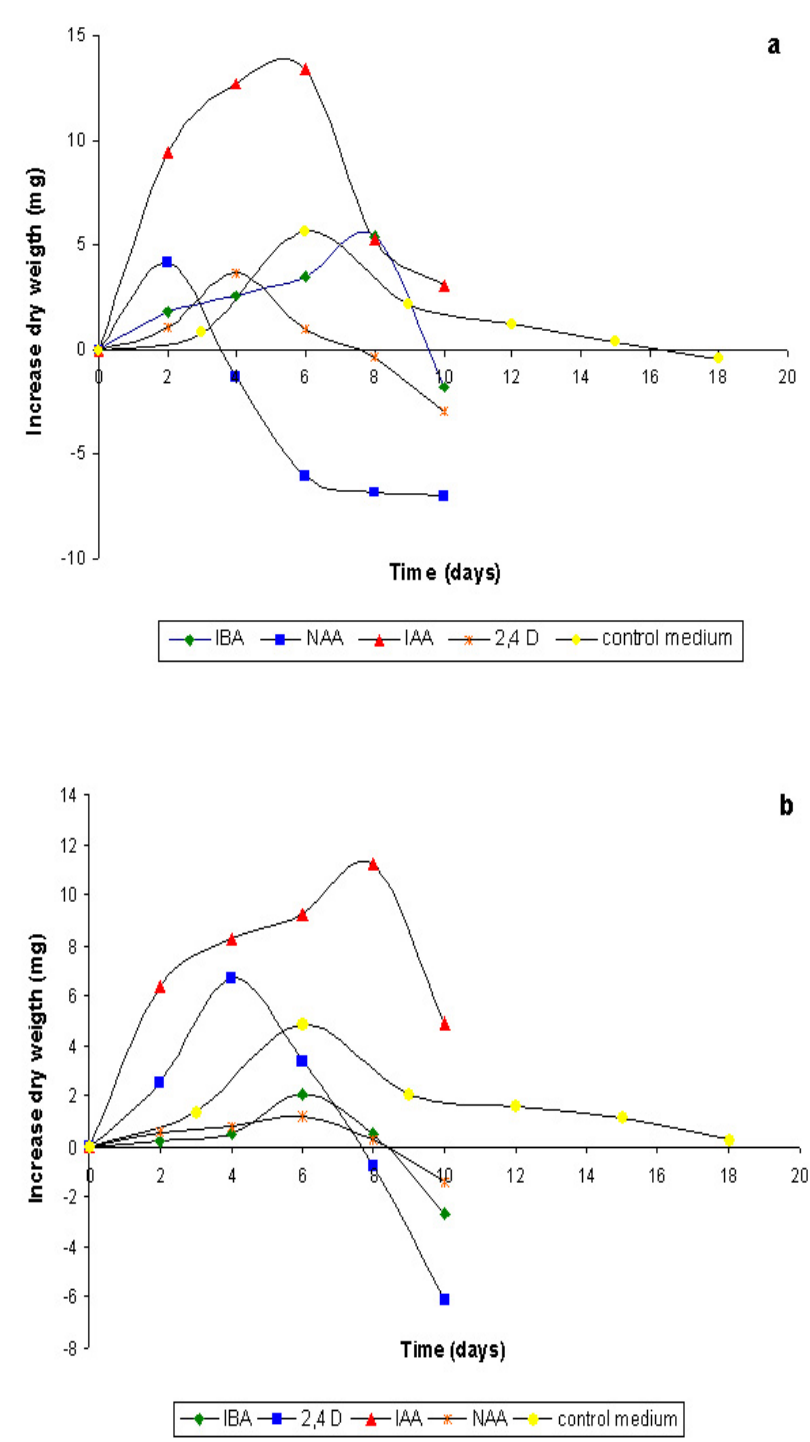

Figure 2. Effect of exogenous auxin $\left(1 \mathrm{mg} \mathrm{L}^{-1}\right)$ on root growth in:

(a) Thypha latifolia.

(b) Scirpus americanus.

americanus were used as inoculum. Different mass was used since $S$. americanus roots were more compact. The $T$. latifolia roots have grown faster using the higher inoculum and reached the maximum at day 9. However, after this time a rapid decrease on growth was observed. With $0.2 \mathrm{~g}$ of roots the growth was constant until day 6 and then it decreased gradually (Figure 1a). In the case of $S$. americanus roots, no growth was observed at any time tested when $0.1 \mathrm{~g}$ of roots was used. With $0.05 \mathrm{~g}$ of roots a rapid increase in dry weight was evident at $6^{\text {th }}$ day decreasing slowly with time (Figure 1b). According to these results, the inoculum selected, for next experiments, were $0.2 \mathrm{~g}$ of $T$. latifolia roots and $0.05 \mathrm{~g}$ of $S$. americanus roots. The decreasing growth observed with the higher inoculum probably is due to a rapid consumption of nutrients from the culture medium and to a consequent starvation of roots.

As the auxins generally promote lateral root formation, we tested the effect of $1 \mathrm{mg} \mathrm{L}^{-1}$ IAA, IBA, NAA or 2,4-D. After 10 days, the growth of roots of $T$. latifolia onto the culture media containing NAA or IBA was lower in comparison with control medium. An increase in biomass was observed until day 4 onto the medium with 2,4-D. The IAA promoted the highest growth of roots reaching the maximum at day 8 (Figure $2 \mathrm{a}$ ). The roots of $S$. americanus presented a similar behaviour. The growth of roots was lower on media with ANA and 2,4-D in comparison with control medium. The highest increase in growth was obtained again with IAA but at day 6 (Figure 2b).

Once selected the auxin promoting the most important increase of growth, we analyzed the effects of different concentration of IAA on rooting. As expected, the exogenous IAA caused abundant lateral roots formation in $T$. latifolia compared with control medium. The increase in radical growth was proportional to the concentration of auxin until 8 day (Figure $3 a$ ). In the case of $S$. americanus roots a small increase in dry weight was observed with 0.1 and $0.5 \mathrm{mg} \mathrm{L}^{-1}$ of IAA but just until day 4. However, using higher concentration of IAA (1-2 $\left.\mathrm{mg} \mathrm{L}^{-1}\right)$ an increase between 3 to 3.5 fold was observed in comparison to control medium (Figure $3 b$ ).

In summary, the optimal conditions to establish the in vitro roots culture corresponded to an inoculum of $0.2 \mathrm{~g}$ of $T$. latifolia roots and $0.05 \mathrm{~g}$ of $S$. americanus roots (fresh weight) and MS medium containing $2 \mathrm{mg} \mathrm{L}^{-1}$ of IAA.

To measure the $\mathrm{Pb}, \mathrm{Cr}$ and $\mathrm{Mn}$ removalby roots the experiments were conducted over a period of 8 days. The results shown that growth of $T$. latifolia and $S$. americanus roots was essentially unaffected by the presence of $\mathrm{Pb}, \mathrm{Cr}$ or Mn onto medium (Table 1). The S. americanus and $T$. latifolia roots removed from the culture medium about $50 \%$ of $\mathrm{Pb}$ at $4 \mathrm{hrs}$, period that was nominated time 0 . The metal was totally captivated at day 4 by $S$. americanus cultures and about $95 \%$ at day 8 by T. latifolia roots. In the case of $\mathrm{Cr}$ its removal was slower reaching only $34 \%$ ( $T$. latifolia) and $47 \%$ (S. americanus) at time 0 . Close of $90 \%$ of metal was removed from the medium at day 4 in both cultures. On the other hand, the removal of Mn was time dependent. The $T$. latifolia roots were able to remove only $70 \%$ of metal at the end of the experiment while those of $S$. americanus removed $100 \%$ at day 8 . These results indicate that both cultures have the ability to efficiently remove the metals without deleterious effect.

Table 2 shows the maximum removal of metal from the solution related to the quantity of root biomass (gram of 
dried weight) that has growth in the culture medium. According to these data $S$. americanus cultures removed between 1.5-3 fold more metals than T. latifolia roots and in a shorter time.

\section{DISCUSSION}

The in vitro roots culture is an ideal system to study the process involved in heavy metals uptake because they can be propagated indefinitely, are very stable, and eliminate the effect of variations between individual seedlings (Pollard and Baker, 1996). Previous papers have demonstrated the effectiveness of in vitro roots cultures to remove metals (Nedelkoska and Doran, 2000). Yet, the metal concentrations in biomass grown in liquid culture are usually greater than those in soil-grown plants due to the greater bioavailability of metal ions in solution.

In this work, we selected the T. latifolia and S. americanus species since they are adapted to grow on presence of heavy metals. To initiate the in vitro culture the roots were cultivated in media with auxins because it is widely accepted that auxins have a central role in adventitious root initiation (Blakesley, 1994). In T. latifolia and $S$. americanus root cultures the auxin IAA promoted the highest root formation. As it is a natural endogenous hormone probably it was rapidly catabolised to a suitable level in cells under strict metabolic regulation (Vuylsteker et al. 1998). It has been described that IAA improves the number and quality of roots in several species because it stimulates the cellular division of radical primordium, promotes the synthesis of specific proteins and increases the sugar release into the phloem (Wilson, 1994). The stimulatory effect of IAA has also been described on in vitro culture of normal and hairy roots of Pueraria lobata (Liu et al. 2002) and horseradish (Nakasimada et al. 1994). The selected conditions allowed the fast growing of roots in the in vitro cultures. To our knowledge, this is the first report that describes a protocol to establish the in vitro root culture of these species.

The T. Latifolia and S. americanus root cultures were able to remove $\mathrm{Pb}$ and $\mathrm{Cr}$ near to $100 \%$ and $71-100 \%$ of $\mathrm{Mn}$ from the medium solution during the 6-8 days of experimentation. The mechanisms of metals removal seems to be characterized by a rapid then by a slower metal concentration decrease in the solution. The rapid decrease could be related to a sorption process at the root surface. Plant cells have an abundance of negatively charged-sites on their walls, so ion-exchange and other interactions between metals and carboxyl, sulphate, amino and other groups are likely to occur (Kratochvil and Volesky, 1998). The sorption of $\mathrm{Pb}, \mathrm{Mn}$ and $\mathrm{Zn}$ to the root surface has been described in wetland plant (Phalaris arundinacea) by microtomography and X-ray microprobe images (Hansel et al. 2001). Adsorption and precipitation at the root surfaces seems to be the mechanism. Other mechanism of short-term removal, such a chelation and covalent binding cannot be discounted.

The slower metal concentration decreasing can be due to an absorption process that should involve transport across the biological membrane and the internalization of the metal. This response could be a critical defensive strategy of the plant, providing time for the development of intracellular mechanism of metal complexation with specific proteins or sequestration onto the vacuole. In the particular case of Thlaspi caerulescens the analysis of root cell wall fractions revealed that the hairy roots partitioned virtually all the $\mathrm{Cd}$ uptake by the biomass in the cell wall fraction for 7 to 10 days before allowing passage into the symplast (Nedelkoska and Doran, 2000). The mechanism of $\mathrm{Cd}$ hyperaccumualtion in this species seems to be related to an efficient antioxidative defense, particularly an enhanced catalase activity (Boominathan and Doran, 2003). Further
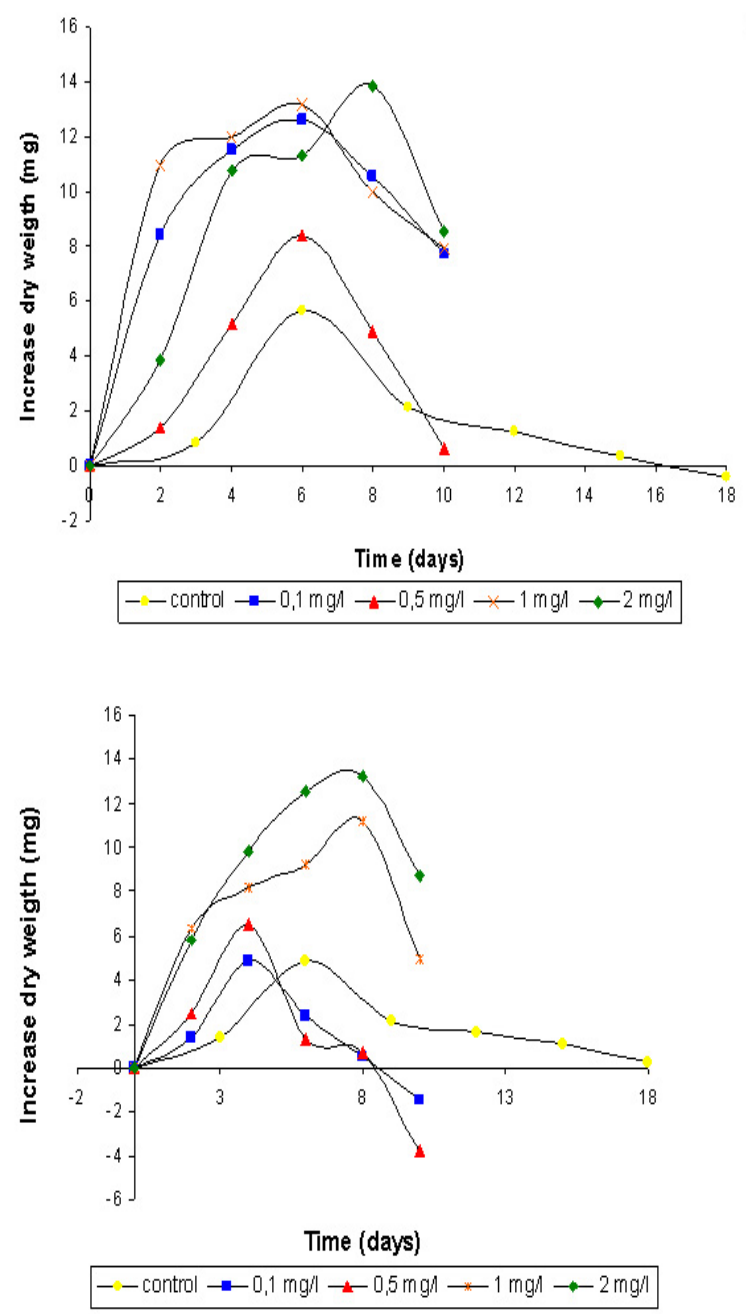

Figure 3. Effect of indolacetic acid concentration on root growth in:

(a) Thypha latifolia.

(b) Scirpus americanus roots. 
studies will be required to define the specific mechanisms of tolerance to $\mathrm{Pb}, \mathrm{Cr}$ and $\mathrm{Mn}$ in S. americanus root cultures. It will be necessary to determine if the metal removal is the result of an adsorption and/or absorption process and which molecules are participating (glutathion, glutathion S-transferase, organic acid, fitoquelatins, methalothioneins, etc.).

On the other hand, the plants have been divided in three arbitrary categories according to the ability to remove metals: normal plants, accumulators and hyperaccumulators. In the particular case for $\mathrm{Cr}, \mathrm{Pb}$ and $\mathrm{Mn}$ metals, an accumulator concentrates more than $50 \mu \mathrm{g} \mathrm{Cr}$ $\mathrm{g}^{-1}, 100 \mu \mathrm{g} \mathrm{Pb} \mathrm{g}^{-1}$ and $2000 \mu \mathrm{g} \mathrm{Mn} \mathrm{g}^{-1}$ dry weight while an hyperaccumulator concentrates $1000 \mu \mathrm{g} \mathrm{g}^{-1}$ of $\mathrm{Cr}$ and $\mathrm{Pb}$, and 10,000 $\mu \mathrm{g} \mathrm{g}^{-1}$ of $\mathrm{Mn}$ (Reeves and Baker, 2000). Considering the quantity of roots used and the metal removed from solution we have calculated the metal concentration removed per gram of tissue. Taking into account these data, the T. latifolia species correspond to the category of normal plants and S. americanus could be considered as an accumulator for $\mathrm{Pb}\left(157.73 \mu \mathrm{g} \mathrm{g}^{-1}\right), \mathrm{Cr}$ $\left(55.6 \mu \mathrm{g} \mathrm{g}^{-1}\right)$ and $\mathrm{Mn}\left(5000 \mu \mathrm{g} \mathrm{g}^{-1}\right)$. To date there are few reports of plants that accumulate $\mathrm{Mn}$ but there are no known $\mathrm{Pb}$ hyperaccumulator plants (Lasat, 2002).

Even when the in vitro root cultures of S. americanus were not a hyperaccumulator it is an interesting model due to its tolerance to several metals. It has been described that plants able to accumulate more than one metal, present some mechanisms that includes the induction of specific enzymes or phytochelatins, and the participation of specific transporters. For example, phytochelatins complexes with $\mathrm{Cd}, \mathrm{Ag}$ and $\mathrm{Cu}$ has been identified on Arabidopsis thaliana, Silene vulgaris, Holcus lanauts, Agrostis castelana and Thlaspi caerulescens (Cobbett, 2000; Schat et al. 2002). The enhanced tolerance to $\mathrm{Cd}, \mathrm{Co}, \mathrm{Cu}, \mathrm{Mg}, \mathrm{Ni}$, $\mathrm{Pb}$ and $\mathrm{Zn}$ in transgenic tomato plants was related to an increase in 1-aminocyclopropane-1-carboxilic acid (ACC) deaminase activity (Grichko et al. 2000) and the tolerance to $\mathrm{Cd}, \mathrm{Co}$ and $\mathrm{Zn}$ in Thlaspi goesingense is related to a CDF present in vacuoles (Hall and Williams, 2003).

The root cultures present an additional advantage to study the mechanisms of tolerance to heavy metals. It is well known that the in vitro production of secondary metabolites can be increased several times by modifying the culture conditions (Charlwood et al. 1990). This strategy could also be used to increase the metal tolerance on $S$. americanus root cultures. There are many examples from the literature describing plants which synthesize and accumulate secondary metabolites (glyceollins) upon treatment with metals. The mechanism proposed suggests that heavy metals induce an oxidative stress. The lipid oxidation process generate oxilipins, signaling molecules responsible for the heavy metal-induced defense response, this is, enzymes, glyceollins, proteins, transporters and/or quelators (Mithöfer et al. 2004).

\section{REFERENCES}

BEN-HAYYIM, Gozal. Relationship between salt tolerance and resistance to polyethylene glycol-induced water stress in cultured Citrus cells. Plant Physiology, October 1987, vol. 85 , no. 2 , p. $430-433$.

BLAKESLEY, D. Auxin metabolism and adventitious root initiation. In: DAVIS, Tim D. and HAISSING, Bruce E. eds. Biology of Adventitious Root Formation. New York, Kluwer Academic/Plenum Press, 1994, p. 143-153.

BOOMINATHAN, Rengasamy and DORAN, Pauline M. Cadmium tolerance and antioxidative defenses in hairy roots of the cadmium hyperaccumulator, Thlaspi caerulescens. Biotechnology and Bioengineering, 2003, vol. 83 , no. 2 , p. $158-167$.

CHARLWOOD, V.B.; CHARLWOOD, K.A. and MOLINA-TORRES, J. Accumulation of secondary compounds by organized plant cultures. In: CHARLWOOD, V. and RHODES, M.J.C. eds. Secondary Products from Plant Tissue Culture. Oxford, Clarendon Press, 1990, p. 167-200.

COBBETT, Christopher S. Phytochelatins and their roles in heavy metal detoxification. Plant Physiology, July 2000, vol. 123 , no. 3 , p. 825-832.

DE LA FUENTE, Juan Manuel; RAMÍREZ-RODRÍGUEZ, Verenice; CABRERA-PONCE, José Luis and HERRERAESTRELLA, Luis. Aluminium tolerance in transgenic plants by alteration of citrate synthesis. Science, June 1997, vol. 276 , no. 5318 , p. 1566-1568.

DE SOUZA, M.P.; PILON-SMITS, E.A. and TERRY, N. The physiology and biochemistry of selenium volatilization by plants. In: RASKIN, I. and ENSLEY, B.D. eds. Phytoremediation of Toxic Metals-using Plant to Clean up the Environment. New York, Wiley, 2000, p. 171-190.

GOLDSBROUGH, Peter. Metal tolerance in plants: the role of phytochelatins and metallothioneins. In: TERRY, N. and BAÑUELOS, G.S. eds. Phytoremediation of Contaminated Soil and Water. Boca Raton, Florida, Lewis, 2000, p. 221-234.

GRICHKO, Varvara P.; FILBY, Brendan and GLICK, Bernard R. Increase ability of transgenic plants expressing the bacterial enzyme ACC deaminase to accumulate $\mathrm{Cd}$, $\mathrm{Co}, \mathrm{Cu}, \mathrm{Ni}, \mathrm{Pb}$ and $\mathrm{Zn}$. Journal of Biotechnology, July 2000 , vol. 81 , no. 1 , p. $45-53$. 
HALL, J.L. and WILLIAMS, L.E. Transition metal transporters in plants. Journal of Experimental Botany, December 2003, vol. 54, no. 393, p. 2601-2613.

HANSEL, Colleen M.; FENDORF, Scott; SUTTON, Steve and NEWVILLE, Matt. Characterization of Fe plaque and associated metals on the roots of mine-waste impacted aquatic plants. Environmental Science and Technology, October 2001, vol. 35, no. 19, p. 3863-3868.

HIMELBLAU, Edward; MIRA, Helena; LIN, Su-Ju; CULOTTA, Valeria Cizewski; PEÑARRUBIA, Lola and AMASINO, Richard M. Identification of a functional homolog of the yeast copper homeostasis gene ATX1 from Arabidopsis. Plant Physiology, August 1998, vol. 117, no. 4, p. 1227-1234.

KARTOSENTONO, Sugijanto; NURAIDA, Ana; INDRAYANTO, Gunawan and ZAINI, Noor Cholies. Phytoremediation of $\mathrm{Sr}^{2+}$ and its influence on the growth, $\mathrm{Ca}^{2+}$ and solasodine content of shoot culture of Solanum laciniatum. Biotechnology Letters, January 2001, vol. 23, no. 2, p. 153-155.

KRAMER, Ute; PICKERING, Ingrid J.; PRINCE, Roger C.; RASKIN, Ilya and SALT, David E. Subcellular localization and speciation of nickel in hyperaccumulator and non-accumulator Thlaspi species. Plant Physiology, April 2000, vol. 122, no. 4, p. 1343-1353.

KRATOCHVIL, David and VOLESKY, Bohumil. Advances in the biosorption of heavy metals. Trends in Biotechnology, July 1998, vol. 16, no. 7, p. 291-300.

LASAT, Mitch M. Phytoextraction of toxic metals: a review of biological mechanisms. Journal of Environmental Quality, January-February 2002, vol. 31, no. 1, p. 109-120.

LIU, Chuanfei; ZHU, Junying; LI, Ling; LIU, Zhili; PAN, Ruichi and JIN, Lehong. Exogenous auxin effects on growth and phenotype of normal and hairy roots of Pueraria lobata (Willd.) Ohwi. Plant Growth Regulation, September 2002, vol. 38, no. 1, p. 37-43.

LYTLE, C. Mel; LYTLE, Farrel W.; YANG, Nancy; QIAN, Jin-Hong; HANSEN, Drew; ZAYED, Adel and TERRY, Norman. Reduction of $\mathrm{Cr}(\mathrm{VI})$ to $\mathrm{Cr}(\mathrm{III})$ by wetland plants: potential for in situ heavy metal detoxification. Environmental Science and Technology, October 1998, vol. 32, no. 20, p. 3087-3093.

MANIOS, Thrassyvoulos; STENTIFORD, Edward I. and MILLNER, Paul A. The effect of heavy metals accumulation on the chlorophyll concentration of Thypha latifolia plants, growing in a substrate containing sewage sludge compost and watered with metaliferus water. Ecological Engineering, March 2003, vol. 20, no. 1, p. 6574.

MCCUTCHEON, Steven C. and SCHNOOR, Jerald L. Phytoremediation, Transformation and Control of Contaminants. John Wiley-Interscience, New Jersey, 2003. 987 p. ISBN 0-471-39435-1.

MITHÖFER, Axel; SCHULZE, Birgit and BOLAND, Wilhelm. Biotic and heavy metal stress response in plants: evidence for common signals. FEBS Letters, May 2004, vol. 566, no. 1-3, p.1-5.

MONTANTE-MONTELONGO, A.D.; ALFARO-DE LA TORRE, M.C. and MEDELLÍN-Milán, P. Estudio geoquímico de elementos traza en una laguna artificial de aguas residuales. Actas del Instituto Nacional de Geoquímica, 1995, vol. 1, p. 33-38.

MURPHY, Angus S.; EISINGER, William R.; SHAFF, Jon E.; KOCHIAN, Leon V. and TAIZ, Lincoln. Early copperinduced leakage of $\mathrm{K}^{+}$from Arabidopsis seedlings is mediated by ion channels and coupled to citrate efflux. Plant Physiology, December 1999, vol. 121, no. 4, p. 13751382.

MURASHIGE, Toshio and SKOOG, Folke. A revised medium for rapid growth and bioassay with tobacco tissue culture. Physiological Plantarum, July 1962, vol. 15, no. 3, p. 473-497.

NAKASIMADA, Yutaka; UOZUMI, Nobuyuki and KOBAYASHI, Takeshi. Stimulation of emergence of root apical meristems in horseradish hairy root by auxin supplementation and its kinetic model. Journal of Fermentation and Bioengineering, 1994, vol. 77, no. 2, p. 178-182.

NEDELKOSKA, Tatjana V. and DORAN, Pauline M. Hyperaccumulation of cadmium by hairy roots of Thlaspi caerulescens. Biotechnology and Bioengineering, March 2000, vol. 67, no. 5, p. 607-615.

PIVETZ, Bruce E. phytoremediation of contaminated soil and ground water at hazardous waste sites. Ground Water Issue USEPA, February 2001, EPA/540/S-01/500, p. 1-27.

POLLARD, A. Joseph and BAKER, Alan J.M. Quantitative genetics of zinc hyperaccumulation in Thlaspi caerulescens. New Phytologist, January 1996, vol. 132, no. 1, p. 113-118.

REEVES, Roger D. and BAKER, Alan J.M. Metalaccumulating plants. In: RASKIN, Ilya and ENSLEY, Burt 
D. eds. Phytoremediation of Toxic Metals Using Plants to Clean UP the Environment. New York, N.Y., John Wiley and Sons, 2000, p. 193-229.

RIVETTA, A.; NEGRINI, N. and COCUCCI, M. Involvement of $\mathrm{Ca}^{2+}$-calmodulin in $\mathrm{Cd}^{2+}$ toxicity during the early phases of radish (Raphanus sativus L.) seed germination. Plant, Cell and Environment, May 1997, vol. 20 , no. 5 , p. $600-608$.

SCHAT, Henk; LLUGANY, Mercè; VOOIJS, Riet; HARTLEY-WHITAKER, Jeanette and BLEEKER, Petra $M$. The role of phytochelatins in constitutive and adaptive heavy metal tolerances in hyperaccumulator and nonhyperaccumulator metallophytes. Journal of Experimental Botany, December 2002, vol. 53, no. 379, p. 2381-2392.

SANTOS-DÍAZ, María del Socorro and OCHOA-ALEJO, Neftalí. PEG-tolerant cell clones of chili pepper: growth, osmotic potentials and solute accumulation. Plant Cell, Tissue and Organ Culture, April 1994, vol. 37, no. 1, p. 18.

VUYLSTEKER, Christophe; DEWAELE, Eric and RAMBOUR, Serge. Auxin induced lateral root formation in chicory. Annals of Botany, March 1998, vol. 81, no. 3, p. 449-454.

WILSON, P.J. The concept of a limiting rooting morphogen on woody stem cuttings. Journal of Horticultural Science, 1994, vol. 69, no. 4, p. 591-600. 